\title{
Analysis of Effects of the Disclosure of Islamic Corporate Governance (ICG) and Islamic Corporate Social Responsibility (ICSR) on Financial Performance (An Empirical Study on the Sharia Banks in Indonesian in 2012-2020)
}

\author{
M. Afif Herliandi Nasution', Azhar Maksum', Idhar Yahya ${ }^{1}$ \\ ${ }^{1}$ Department of Accounting, Faculty of Economics and Business at Universitas Sumatera Utara, Indonesia.
}

Corresponding Author: M. Afif Herliandi Nasution

DOI: https://doi.org/10.52403/ijrr.20220248

\begin{abstract}
The objective of the research is to determine the effects of the disclosure of Islamic Corporate Governance (ICG) and Islamic Corporate Social Responsibility (ICSR) on financial performance. The amount of ICG and ICSR disclosure can measure from the disclosure score compiled based on the standards of the IFSB, AAOIFI, and relevant previous studies. Profitability ratios measure financial performance in the form of ROA.

The population in the research is the Sharia Commercial Bank (BUS) in the period 2012-2020. The research uses pooling data as the sampling method to obtain 109 observational data, which was analyzed using SmartPLS 3.2 and SPSS 23 software. The result shows that the level of disclosure of financial statements from Islamic Commercial Bank shows a good level of disclosure of ICG and ICSR, 74\% and 68\%, respectively. The result of empirical testing proves that the disclosure of ICG and ICSR has a direct effect positively and significantly on financial performance.
\end{abstract}

Keywords: disclosure, ICG, ICSR, financial performance

\section{INTRODUCTION}

Developments throughout the world have affected various aspects of life globally, one of which is the economy and banking. The economic and banking system has been used a lot and continues to grow. However, these developments are not limited to rules. When a transaction occurs, many losses from various parties, one of which is interest practice. In Islam, practices like this are not justified because it is considered forbidden.

At present Islamic finance globally continues to experience growth. The Islamic Financial Services Board (IFSB) reported that the global Islamic banking industry experienced an increase of $0.9 \%$ of asset growth with financial NIAI around USD 1.57 trillion. From Table 1. It showed that Islamic financial conditions consist of banking assets, outstanding Sukuk, Islamic Funds Assets, Takaful Contributions. Regionally in the top of the 5 regions, namely the Asian region represented by countries such as Indonesia and Malaysia, the Gulf Region or the GCC (Gulf Cooperation Council). The Middle East, in addition to the GCC, namely Mena (the Middle East and North Africa), is scattered to other countries such as Turkey, Britain, and Germany. 
M. Afif Herliandi Nasution et.al. Analysis of effects of the disclosure of Islamic corporate governance (ICG) and Islamic corporate social responsibility (ICSR) on financial performance (an empirical study on the Sharia Banks in Indonesian in 2012-2020).

Table 1. Islamic Finance Globally Based On The Region Of 2018 (Billion USD)

\begin{tabular}{|l|l|l|l|l|}
\hline Region & Banking Assets & Outstanding Sukuk & Islamic Funds Assets & Takaful Contributions \\
\hline Asia & 266.1 & 323.2 & 24.2 & 4.1 \\
\hline GCC & 704.8 & 187.9 & 22.7 & 11.7 \\
\hline MENA (ex - GCC) & 540.2 & 0.3 & 0.1 & 10.3 \\
\hline Africa (ex-North) & 13.2 & 2.5 & 1.5 & 0.01 \\
\hline Others & 47.1 & 16.5 & 13.1 & - \\
\hline Total & $1,571.3$ & 530.4 & 61.5 & 27.7 \\
\hline
\end{tabular}

Of all the fields of Islamic financial segments, Islamic banks that dominate Islamic finance are almost $72 \%$. It proves that Islamic banks have a bright future with consistent growth in the past few years.

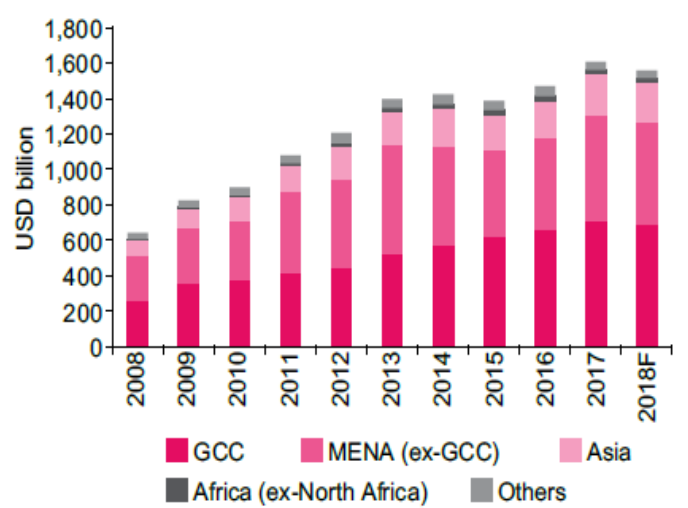

Source: Islamic Financial Services Board Report 2018, IFSB Figure 1. The Development Of Sharia Bank Assets In The World

According to the Islamic Finance Country Index (IFCI), in 2019, Indonesia became a country with leadership and potential in Islamic Banking and Finance (IBF) globally. The factors that caused support from President Joko Widodo led the Islamic Finance Committee (IFC) to promote Islamic finances and be supported by Bank Syariah Mandiri (BSM) as a global leader in IBF even though the main focus of the National Market / domestic. The Global Islamic Finance Awards (GIFA) and the Islamic Retail Banking Awards (IRBA) have recognized BSM recently.

As the country with the largest Muslim population, it is appropriate for Indonesia to become a pioneer and the Qibla development of the Islamic financial industry in the world. It is not an impossible dream because of Indonesia's potential and opportunity to become a global Islamic financial player, especially in facing MEA, including: (i) The number of the large Muslim population is the potential of sharia financial industry customers;

(ii) The outlook for bright economic, reflected in relatively high economic growth (range 6.0\% -6.5\%) supported by solid economic fundamentals;

(iii)Increased Sovereign Credit Rating Indonesia became an investment-grade that will increase investor interest in investing in the domestic financial sector, including the Islamic financial industry; and

(iv)has abundant natural resources that can make it the underlying transaction for the Islamic finance industry (Kemenkeu, 2015).

Table 2. Latest IFCI Scores \& Ranks 2019

\begin{tabular}{|l|l|l|l|}
\hline Countries & $\begin{array}{l}\mathbf{2 0 1 9} \\
\text { Rank }\end{array}$ & $\begin{array}{l}\mathbf{2 0 1 8} \\
\text { Rank }\end{array}$ & $\begin{array}{l}\text { Changes } \\
\text { Rank }\end{array}$ \\
\hline Indonesia & 1 & 6 & +5 \\
\hline Malaysia & 2 & 1 & -1 \\
\hline Iran & 3 & 2 & -1 \\
\hline Saudi Arabia & 4 & 3 & -1 \\
\hline Sudan & 5 & 11 & +6 \\
\hline Brunei Darussalam & 6 & 14 & +8 \\
\hline United Arab Emirates & 7 & 4 & -3 \\
\hline Bangladesh & 8 & 10 & +2 \\
\hline
\end{tabular}

Source: Islamic Finance Country Index Report 2019

In Asian countries, especially Southeast Asia, the population of Islam is indeed a world concern about its relation to Islamic financial development. The ability of the Islamic financial industry in the country in the face of the currency crisis in late 1990 and the other global financial crisis at least gave up the recognition of the importance of the country's position in retaining its company, especially in the field of Islamic finance. Rapid and consistent growth also makes Southeast Asia an important part of global Islamic finance.

After the recent global financial crisis, Islamic banking's reputation must be 

Islamic corporate social responsibility (ICSR) on financial performance (an empirical study on the Sharia Banks in Indonesian in 2012-2020).

maintained through customer-oriented policies. Islamic finance may be an alternative model suitable for finance in the modern world. Growing recognition is given to Islamic financial products in several European and American financial and insurance institutions after the era of postfinancial crisis prove that Islamic finance has achieved substantial growth in the past two decades, the annual growth rate of around 14 percent over the past 15 years (Farook et al. 2011 ).

Karapistic of a Syariah Banking System that operates based on the principle of profit-sharing gives an extraordinary benefit for the community and banks and highlights aspects of justice in transactions, ethical investments put forward the values of togetherness and brotherhood in producing and avoiding speculative activities in a financial transaction (OJK, 2017).

It is because the disclosure of CSR is an important company in the governance of a company and management. Especially to find out the effect of CSR on company performance, especially financial performance. These findings state that CSR is expensive because it is socially responsible for additional costs. If the company's financial performance is low, investors are hesitant to secure capital in the company, consequently reducing the company's value.

Financial performance in the business world has a very broad meaning. The Indonesian Public Accountant Association (2007) defines financial performance as managing and controlling company resources. Financial performance is a picture of the company's financial position for a certain period regarding funding and allocation aspects and is usually measured using capital adequacy indicators, liquidity, and profitability (Jumingan, 2006). Financial performance is the achievement of a company's success and results from various activities. Financial performance is an analysis conducted to ensure that a company has performed well and correctly using the financial implementation rules (Fahmi, 2012).

The rapid development of Islamic banking is not separated from good practice, namely implementing the principles of corporate governance $(\mathrm{CG})$ as a reference for daily activities and corporate social responsibility (CSR) as a commitment to social responsibility for the environment. The application of CG is different between conventional banks and Islamic banks due to many parties involved, such as investors and stakeholders, regulators, and Islamic communities that directly interest the stability of the Islamic banking system (Rihab and Hamadi, 2014).

CG is a fundamental framework for monitoring company behavior. It is relatively more important for institutional financial governance. Corporate governance is a process, policy, rules, and institutions that affect a company's direct management and control. This larger CG emphasis is because different account holders and investors own funds managed by different banks. It implies that every mistake in the bank can be detrimental, which will impact stakeholders. In addition, it can cause problems and agency conflicts of interest between management and parties that have shown their belief in banks with financial institutions for the management of their better funds (Khuram et al., 2013).

Sharia banks tend to have different system characteristics from conventional banks. Islamic finance does not allow interest payments (usury). At the same time, Islamic finance depends on the idea of risksharing, both on profits and losses. It will show a clear difference between Islamic banks and conventional. This difference allows us to capture the relatively clear governance image of the mechanism in the bank and its contribution to improving performance. However, it does not predict whether the difference in governance practice in both bank performance causes different performance (amines, 2018).

Several studies try to provide alternative corporate governance models for 
M. Afif Herliandi Nasution et.al. Analysis of effects of the disclosure of Islamic corporate governance (ICG) and Islamic corporate social responsibility (ICSR) on financial performance (an empirical study on the Sharia Banks in Indonesian in 2012-2020).

companies that apply Sharia principles from an Islamic perspective. Studies show that sharia companies can adopt the corporate governance model of the values of Islamic teachings, which are completely different from Western models such as Anglo-Saxon models and European models (Hamid et al., 2011).

According to Bhatti \& Bhatti (2010), ICG aims to direct economic actors, legal systems, and corporate governance to moral and social values based on sharia systems. Various economic activities, companies, and business activities are based on the Etrhoreligious paradigm with one goal: the welfare of individuals and the community. ICG has a goal equation with corporate governance in general, but ICG refers to the values of Islam. ICG tried trying to combine Islam with stakeholder models in Corporate Governance. According to Lewis (2005), ICG has two traits. First, all aspects of the company's life, ethics, and corporate social problems must refer to Islamic law. Second, ICG also has business ethics and economic and financial principles of Islam, among them related to the command and prohibited commands in Islam, namely zakat, the prohibition of usury, prohibition of speculation, and orders to develop economic systems based on joint advantages and disadvantages.

Some previous studies related to ICG can be seen in two models. The first presents a different corporate governance model from the conventional corporate governance model that has been developed before. Second, the ICG model innovated from the Stakeholders (Hasan, 2011) model. The first model developed by Choudhury \& Hoque (2006) is based on the principle of Shura/deliberation where all stakeholders have the same goal, namely Tauhid and the oneness of Allah SWT. In contrast, the second model is an innovation of the stakeholder model Iqbal \& Mirakhor (2004) and Chapra \& Ahmed (2002).

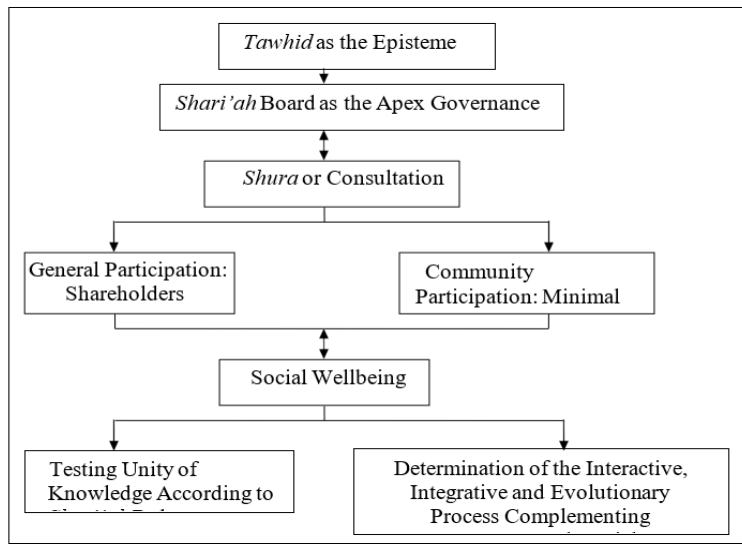

Figure 2. Source: Choudhory \& Hoque (2004)

Table 3. Model ICG Tawhid and Shura Based

\begin{tabular}{|c|c|c|c|}
\hline Aspect & Anglo-Saxon & European Model & Islamic Model \\
\hline Epistemology & Rationalism and Rationality & Rationalism and Rationality & Tawhid \\
\hline Purpose & 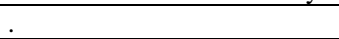 & & \\
\hline Rights and Interests & $\begin{array}{l}\text { To protect the interests and } \\
\text { rights of shareholders. }\end{array}$ & $\begin{array}{l}\text { To maintain the rights of the } \\
\text { community with the corporation. }\end{array}$ & $\begin{array}{l}\text { To protect the interests and rights of all } \\
\text { stakeholders but subject to sharia rules. }\end{array}$ \\
\hline Company Goal & $\begin{array}{l}\text { Shareholders controlling } \\
\text { managers for purposes } \\
\text { Shareholder's advantage }\end{array}$ & $\begin{array}{l}\text { People control for social welfare } \\
\text { purposes }\end{array}$ & $\begin{array}{l}\text { Acknowledge oriented on profit motives } \\
\text { but balance it with sharia's goals and } \\
\text { principles }\end{array}$ \\
\hline $\begin{array}{l}\text { Management } \\
\text { Characteristics }\end{array}$ & Dominate management & Control shareholders dominate & Concept of the Caliphate and Shura \\
\hline Management Board & One-tier board & Two-tier board & $\begin{array}{l}\text { Two-Tier Board with a Sharia Council in } \\
\text { the top position }\end{array}$ \\
\hline $\begin{array}{l}\text { Capital Ownership } \\
\text { Structure }\end{array}$ & $\begin{array}{l}\text { Extensive capital ownership } \\
\text { dividends are prioritized. }\end{array}$ & $\begin{array}{l}\text { Banks and companies are the main } \\
\text { shareholders; Dividends are less } \\
\text { prioritized. }\end{array}$ & Shareholders, Depositors, and Investors \\
\hline
\end{tabular}

Source: Hasan (2011)

According to Choudhory \& Iqbal (2004), there are four principles and instruments that regulate the corporate governance in an Islamic perspective, namely the extension of the Tauhid through an interactive, integrative and evolutionary process, the principle of justice, the involvement of resources on social and economical, and recursive intentions between the stages. Figure 3 illustrates that the ICG approach is based on the epistemological model of Tawhid (Tawhid 

Islamic corporate social responsibility (ICSR) on financial performance (an empirical study on the Sharia Banks in Indonesian in 2012-2020).

is the Episteme), where the company's rules function works through sharia rules. The principle of Tawhid comes from the concept of caliph, mandate, justice, or balance. Two institutions have an important role in ICG, namely the Sharia Board and the Shura Council (Shura), ensuring the company's activities align with the Sharia Principles. This approach still requires a deeper development to be applied to Islamic financial institutions.

According to Chapra \& Ahmed (2002), in Islam's view, CG emphasizes the idea of justice to protect the rights of all stakeholders, both for capital providers and not. According to Iqbal \& Mirakhor (2004), this view follows the Corporate Governance model in the Islamic economy is a centralized stakeholder model where the governance and structure of the company protect the interests and rights of stakeholders. They see the basic concepts of Islamic law, namely the concept of ownership and agreement commitment in Islam, which regulates individual behavior, communities, and countries.

ICG is carried out based on sharia principles for all stakeholders, including shareholders, management, other stakeholders, depositors, employees, suppliers, and the general public. The Sharia Committee guarantees to monitor and ensure the company's activities do not violate sharia law. The Board of Directors ensures that business activities are going well and shareholders and many stakeholders can benefit from them. In comparison, the government provides definite regulation (Hasan, 2011).

Overall, unlike the CG concept in a Western perspective, ICG is rooted in the basic principles of Tawhid, the process of Shura, property rights, and contractual obligations. Islamic banks, including several important roles in ICG in Islamic financial institutions, especially the board of directors, shareholders, depositors, managers, and especially the Sharia Supervisory Board, must be able to ensure sharia goals and company goals can be achieved in the frame of Islamic rules and Islamic values. Along with the development of Islamic financial institutions such as Islamic banks today, Corporate Governance is needed, outlined in the form of "Syariah Governance" as part of ICG.

Some of the results of previous studies showed that the disclosure of the CG Syariah Bank was still low (an average of 50\%). According to Darmadi's findings (2013), the level of disclosure of ICG in 11 Islamic banks in Indonesia in 2010 was only 52\%. Abdullah et al. (2015) stated that the disclosure of ICG in 67 Islamic banks in GCC countries in 2009 was only $37 \%$. Majid et al. (2015) CG disclosure at 16 Islamic banks in Malaysia in 2009 was $51 \%$. Meanwhile, the latest survey by Sraeli (2015) only contributed $54 \%$ of the disclosure of the GCC Syariah Bank.

In addition to the importance of disclosure of ICG in sharia banking, there are other important issues, namely Corporate Social Responsibility (CSR). CSR is a social activity against stakeholders in the form of attention to raising welfare \& has a positive impact on residents more or less for the environment around the company's scope.

Various experts from the West try to provide theory, moral, and ethical reasons in CSR development. However, this effort has been widely criticized because it does not provide adequate ethical guidance on justification (justification), conceptual clarity, and the possibility of inconsistency and fails to provide sufficient ethical guidance for business executives, which to pursue and the level of commitment. Therefore, the CSR concept needs to be developed and widely accepted by the West and Islamic business community, especially from the Islamic point of view (Khurshid et al., 2014).

Williams and Zinkin (2010) see the comparison between Islamic principles with the CSR concept of the United Nations in the Global Compact, which includes human rights, workers' rights, environmental issues, and anti-corruption principles. They argue 
M. Afif Herliandi Nasution et.al. Analysis of effects of the disclosure of Islamic corporate governance (ICG) and Islamic corporate social responsibility (ICSR) on financial performance (an empirical study on the Sharia Banks in Indonesian in 2012-2020).

that the concept of Islam has wider coverage than Global Compact. First, Islam has wider coverage, for example, in terms of developing human resources and in terms of transparency in transactions. Second, Islam has clear rules about what is allowed (halal) and prohibited (haram). Third, Islam has a good and right sharia enforcement mechanism in carrying out his Shari'a.

ICSR provides a more comprehensive explanation of the relationship between sharia entities, namely the relationship of responsibility for God, humans, and the environment, classified into three dimensions (Joseph \& Maritime, 2015). It is necessary to have four principles to fulfill this responsibility: the oneness of God (Unity of Allah), Khilafah, justice, and brotherhood to create mashallah for the community and the environment. Maslahah is the main goal of ICSR. The ICSR implementation must fulfill the halal elements and leave the unclean element. The basic principles of ICSR practices are expected to meet the needs of all stakeholders in sharia entities.

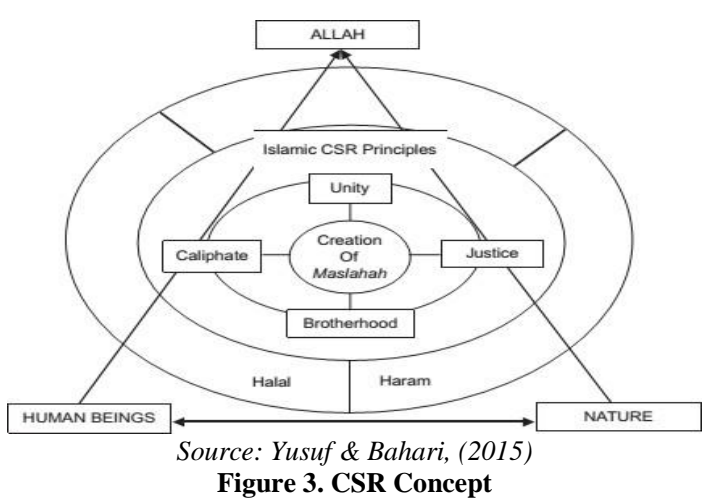

Khurshid et al. (2014) divided the ICSR into four aspects:

1. Islamic Economic Responsibility, the benefits obtained by Islamic companies must be free of something that is forbidden in Islam.

2. Islamic Legal Responsibility, Islamic companies, must comply with Islamic law and applicable laws that apply

3. Islamic ethical responsibility, running business activities must be following the value of Islamic ethics

4. Islamic Philanthropic Responsibility, companies can contribute to the community through Islamic philanthrification.

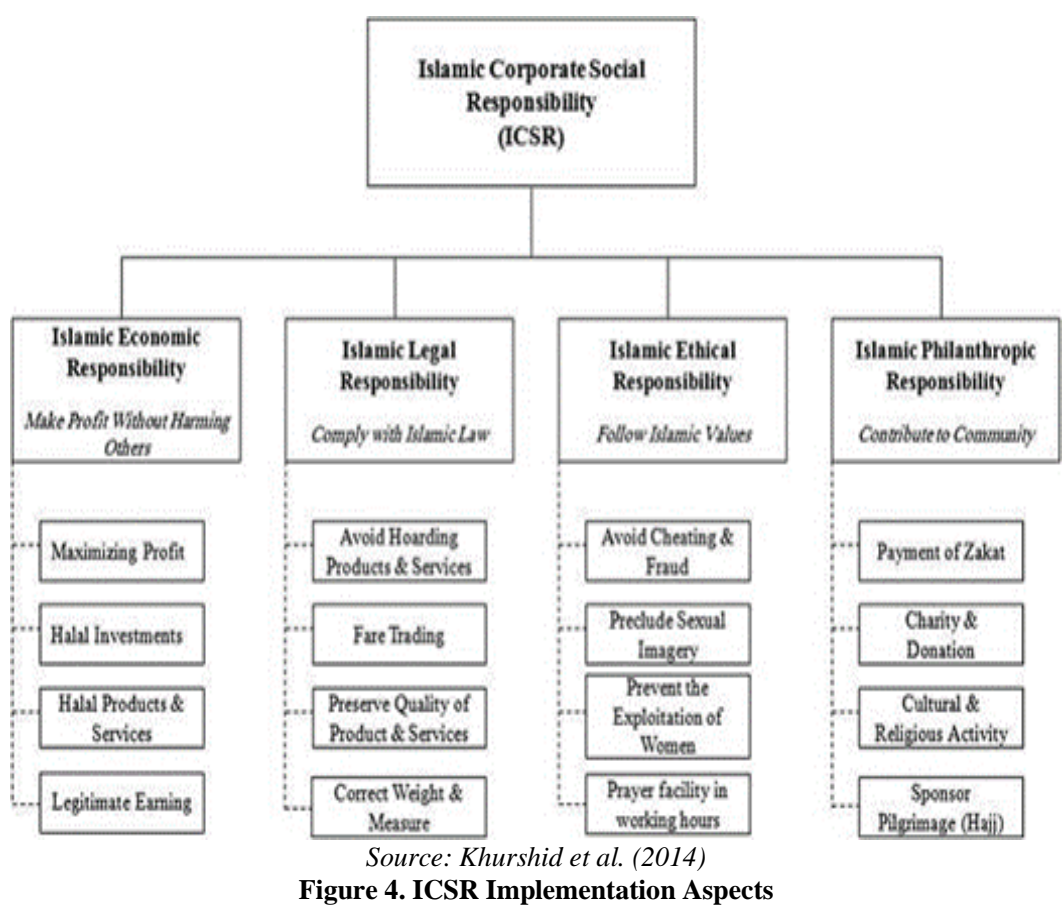

Research Arshad et al. (2012) concerning CSR, company reputation, and performance in 17 Islamic banks in
Malaysia from 2008-2010. Providing evidence that CSR activities communicated in the company's annual report are 
M. Afif Herliandi Nasution et.al. Analysis of effects of the disclosure of Islamic corporate governance (ICG) and Islamic corporate social responsibility (ICSR) on financial performance (an empirical study on the Sharia Banks in Indonesian in 2012-2020).

significantly positively related to the company's reputation and company performance. Similarly, Yadiat et al. (2017) researched CSR disclosures at Islamic banks by comparing 2 countries, namely Indonesia and Malaysia. The Disclosure of Sharia Bank CSR results grows well in both countries.

However, several previous studies showed that Islamic banks still had a low level of CSR disclosure (an average of less than 50\%). Hassan \& Harahap (2010) 38\%, Aribi \& Gao (2010) 30\%, Farook, et al (2011) 16.8\%, Mosaid \& Bouti (2012) 25\%, Kamla \& Rammal (2013) 39\%, Farag, et al (2014) 44\%, El Halaby \& Hussainey (2015) $26 \%$. Some studies show that Islamic banks have a high level of CSR disclosure $(50 \%$ or more), such as Sofyani et al. (2012) and Rahman \& Open (2013) 83\%.

According to Kamaludin (2011), the profitability ratio shows a grain of the level of effectiveness of the company's management in generating profits. According to Munawir (2010), return on assets is one form of the profitability ratio intended to measure the company's ability with the whole funds used for the company's operations to produce profits. This ratio is a gauge of whether the owner or shareholder can obtain an appropriate rate of return on his investment. To measure the financial performance ratio, Return on Asset (ROA). This ratio is used to measure bank management capabilities in gaining overall profits. One success measures a company's financial performance by measuring the rate of return on assets or return on assets (ROA), which can certainly make a benchmark in returning the company's decision. If the greater ROA means more efficient use of company assets or, in other words, with the same number of assets, can produce greater profits, and vice versa.

Based on the description conveyed in the background, it can be seen that the level of disclosure of CG and CRS at Islamic banks in a country with a sharia bank is still limited. There are also results from previous studies that stated that they were still low in disclosure of CG and ICG against Islamic banks. These problems lift researchers in this study, namely measuring how CG and CSR disclosures on the company's value at Islamic banks in Indonesia and finding out whether financial performance also took an important role in this study.

\section{Framework}

Following the description of the background of the problem, literature review, and previous research, a conceptual research framework is prepared as follows:

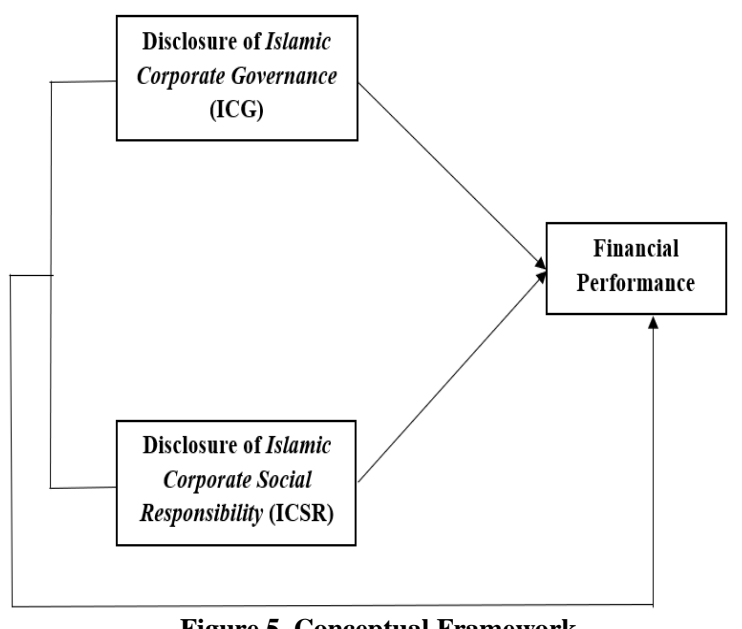

Figure 5. Conceptual Framework

H1: Disclosure of Islamic Corporate Governance (ICG) positively affects financial performance.

H2: Disclosure of Islamic Corporate Social Responsibility (ICSR) positively affects financial performance.

H3: Disclosure of Islamic Corporate Governance (ICG) and Islamic Corporate Social Responsibility (ICSR) simultaneously positively affect financial performance.

\section{RESEARCH METHODS}

The type of research used in this study is descriptive research. According to Singh (2006), descriptive research is research relating to the current situation that intends to explain the status of the phenomenon investigated. In this study, research is intended to explain the influence of disclosure of ICG and ICSR on financial 
M. Afif Herliandi Nasution et.al. Analysis of effects of the disclosure of Islamic corporate governance (ICG) and Islamic corporate social responsibility (ICSR) on financial performance (an empirical study on the Sharia Banks in Indonesian in 2012-2020).

performance. The data collection technique used is a questionnaire (questionnaire). The data analysis method is used in this study is a statistical analysis method using the smart pls application. Data Analysis Performs by Testing Standard Assumptions and Testing Hypotheses.

The population in this study were all Islamic commercial banks (buses) registered in OJK in 2020. The list of these populations was taken from Islamic banking statistics for August 2020. 14 sharia commercial banks (bus) became the study population. The samples used in this study were saturated samples, namely sampling techniques with all population members used as samples (Static, 2019).

The period of testing in this study was for 8 years, with the research source in the form of financial statements of the publication of each bank from 2012-2020. In this study, Bank Syariah Bukopin, Bank Jabar Banten Syariah, Bank Aceh Syariah and Bank BPD NTB Syariah could not be measured for 9 years. The new National Pension Savings Bank (BTPN) of Sharia has been operating as a Sharia Commercial Bank since 2014, Bank Aceh Syariah since 2016, and Bank BPD NTB Syariah operates with a Sharia System since 2018. The total has 97 ratio data.

\section{RESULT AND DISCUSSION \\ Descriptive Statistical Analysis}

Descriptive statistical analysis of research is used to provide an overview of the variables used in research that describe respondents' perceptions or opinions on the questions submitted.

\begin{tabular}{|c|c|c|c|}
\hline $\begin{array}{l}\text { Descripti } \\
\text { ve }\end{array}$ & $\begin{array}{l}\text { Financial } \\
\text { Performance }\end{array}$ & ICSR & ICG \\
\hline Min & -20.13 & 51.28 & 71.88 \\
\hline Max & 13.6 & 74.36 & 75 \\
\hline Mean & 0.83112 & 67.52752 & 73.46496 \\
\hline Std. Dev. & 3.646830974 & 5.439011363 & 0.523577372 \\
\hline
\end{tabular}

Based on table 4. above, it can be seen that the financial performance variable has the lowest value of -20.13 and the highest value of 13.6 with an average value of 0.83112 , while the standard deviation value is 3.6468 . The ICSR variable has the lowest value of 51.28, and the highest of ICSR is 74.36, with the average value of the ICSR being 67,527, while the standard value of the deviation from ICSR is 5.439. The ICG variable has the lowest value of 71.88 , and the highest value of ICG is 75, with the average value of ICG being 73.46, while the standard value of the deviation from ICG is 0.5235 .

\section{Test Effectiveness}

Table 5. Test Effectiveness Result

\begin{tabular}{|c|c|c|c|c|c|}
\hline & $\begin{array}{c}\text { Original } \\
\text { Sample } \\
(\mathbf{0})\end{array}$ & $\begin{array}{c}\text { Sample } \\
\text { Mean } \\
\text { (MI) }\end{array}$ & $\begin{array}{c}\text { Standard } \\
\text { Deriation } \\
\text { (STDEV) }\end{array}$ & $\begin{array}{c}\text { TStatistics } \\
\text { (0ITDEV) }\end{array}$ & $\begin{array}{c}\text { P } \\
\text { Values }\end{array}$ \\
\hline ICG $>$ Financial Performance & 0.255 & 0.260 & 0.095 & 2.693 & 0.007 \\
\hline ICSR $\rightarrow$ Financial Performance & 0.297 & 0.289 & 0.112 & 2.650 & 0.008 \\
\hline
\end{tabular}

Source: Data is processed by researchers in 2021

Based on the results in Table 5. Results are obtained:

1. ICG has a positive effect on financial performance, with a path coefficient (original sample) 0.255 , and significant, with a value of $\mathrm{p}$-values $=0.007<0.05$ (H1 Accepted).

2. ICSR has a positive effect on financial performance, with a line coefficient (original sample) of 0.297, and significant, with a value of $\mathrm{p}$-values $=$ $0.008<0.05$ (H2 Accepted).

\section{Determination Coefficient Test $\left(\mathbf{R}^{2}\right)$}

Table 6. Determination Coefficient Test Result

\begin{tabular}{|l|l|}
\hline & R Square \\
\hline Financial Performance & 0.142 \\
\hline \multicolumn{2}{|c|}{ Source: Data is processed by researchers in 2021} \\
\hline
\end{tabular}

Based on the results in Table 6 , RSquare values of financial performance are 0.142, which means ICG and ICSR can explain the financial performance of $14.2 \%$. 
M. Afif Herliandi Nasution et.al. Analysis of effects of the disclosure of Islamic corporate governance (ICG) and Islamic corporate social responsibility (ICSR) on financial performance (an empirical study on the Sharia Banks in Indonesian in 2012-2020).

\section{Simultaneous Test}

Table 7. Simultaneous Test Result

\begin{tabular}{|c|c|c|c|c|c|c|}
\hline \multicolumn{7}{|c|}{ ANOVA } \\
\hline \multicolumn{2}{|c|}{ Model } & Sum of Squares & df & Mean Square & $\mathbf{F}$ & Sig. \\
\hline \multirow[t]{3}{*}{1} & Regression & 233.817 & 2 & 116.909 & 10.078 & $.000^{\mathrm{a}}$ \\
\hline & Residual & 1415.305 & 122 & 11.601 & & \\
\hline & Total & 1649.123 & 124 & & & \\
\hline \multicolumn{7}{|c|}{ a. Predictors: (Constant), ICG, ICSR } \\
\hline \multicolumn{7}{|c|}{ ependent Variable: Financial Performance } \\
\hline
\end{tabular}

Based on table 7 above, the GIS value is obtained. $0,000<0.05$, it is concluded that ICG and ICSR simultaneously significantly affect financial performance (H3 Accepted).

\section{The Level Of Disclosure Of ICG And ICSR At Islamic Banks In Indonesia}

The first step to this study is disclosing Islamic bank financial statements in Indonesia in the 2012-2020 period. The level of disclosure can be seen in the attachment. As an illustration, the following is presented by the level of disclosure carried out by each Islamic bank in Indonesia in 2012-2020.

Table 8. The Level Of Disclosure Of ICG At Islamic Banks In Indonesia

\begin{tabular}{|l|l|l|}
\hline No & Islamic Bank & $\begin{array}{l}\text { Average } \\
\text { Disclosure }\end{array}$ \\
\hline $\mathbf{1}$ & Bank Aceh Syariah & $73,05 \%$ \\
\hline $\mathbf{2}$ & BPD Nusa Tenggara Barat Syariah & $74,48 \%$ \\
\hline $\mathbf{3}$ & Bank Muamalat Syariah & $75,35 \%$ \\
\hline $\mathbf{4}$ & Bank Victoria Syariah & $74,31 \%$ \\
\hline $\mathbf{5}$ & Bank BRI Syariah & $74,48 \%$ \\
\hline $\mathbf{6}$ & Bank BNI Syariah & $75,17 \%$ \\
\hline $\mathbf{7}$ & Bank Jabar Banten Syariah & $74,33 \%$ \\
\hline $\mathbf{8}$ & Bank Syariah Mandiri & $74,48 \%$ \\
\hline $\mathbf{9}$ & Bank Mega Syariah & $75,20 \%$ \\
\hline $\mathbf{1 0}$ & Bank Panin Dubai Syariah & $75,00 \%$ \\
\hline $\mathbf{1 1}$ & Bank Syariah Bukopin & $75,00 \%$ \\
\hline $\mathbf{1 2}$ & BCA Syariah & $74,48 \%$ \\
\hline $\mathbf{1 3}$ & Bank Tabungan Pensiunan Nasional & $74,11 \%$ \\
\hline $\mathbf{2}$ & Syariah & $75,00 \%$ \\
\hline $\mathbf{1 4}$ & Maybank Syariah Indonesia \\
\hline
\end{tabular}

In the 2012-2020 period, the level of disclosure of ICG in each annual report of Islamic commercial banks in Indonesia ranged from $70 \%$ - to $76 \%$. The average disclosure level was $74.60 \%$. These results indicate that the level of ICG disclosure is quite good. The highest disclosure level was carried out by Bank Muamalat, with a disclosure level of $75.35 \%$. At the same time, Bank Aceh Syariah carried out the lowest disclosure by $73.05 \%$. This good level of disclosure can be concluded because there is still no regulatory regulation for Islamic banks in Indonesia. Both Indonesian accountants and financial services authorities require Islamic financial institutions, especially Islamic banking in Indonesia, to disclose corporate governance in their financial statements below items specified in the IFSB accounting standards.

Table 9. The Level Of Disclosure Of ICSR At Islamic Banks In Indonesia

\begin{tabular}{|l|l|l|}
\hline No & Islamic Bank & $\begin{array}{l}\text { Average } \\
\text { Disclosure }\end{array}$ \\
\hline $\mathbf{1}$ & Bank Aceh Syariah & $72,44 \%$ \\
\hline $\mathbf{2}$ & BPD Nusa Tenggara Barat Syariah & $75,21 \%$ \\
\hline $\mathbf{3}$ & Bank Muamalat Syariah & $67,24 \%$ \\
\hline $\mathbf{4}$ & Bank Victoria Syariah & $51,28 \%$ \\
\hline $\mathbf{5}$ & Bank BRI Syariah & $68,66 \%$ \\
\hline $\mathbf{6}$ & Bank BNI Syariah & $66,67 \%$ \\
\hline $\mathbf{7}$ & Bank Jabar Banten Syariah & $68,86 \%$ \\
\hline $\mathbf{8}$ & Bank Syariah Mandiri & $67,81 \%$ \\
\hline $\mathbf{9}$ & Bank Mega Syariah & $70,19 \%$ \\
\hline $\mathbf{1 0}$ & Bank Panin Dubai Syariah & $70,09 \%$ \\
\hline $\mathbf{1 1}$ & Bank Syariah Bukopin & $70,66 \%$ \\
\hline $\mathbf{1 2}$ & BCA Syariah & $69,80 \%$ \\
\hline $\mathbf{1 3}$ & Bank Tabungan Pensiunan Nasional & $68,86 \%$ \\
\hline $\mathbf{1 4}$ & Syariah & $69,55 \%$ \\
\hline & Saybank Syariah Indonesia & \multicolumn{2}{|c|}{ Source: Data is processed by researchers in 2021} \\
\hline
\end{tabular}

In the 2012-2020 period, the level of Disclosure of ICSR in each annual report of Islamic commercial banks in Indonesia ranged from $50 \%$ - to $72 \%$. The average disclosure level was $68.38 \%$. These results indicate that the level of ICSR disclosure is quite good. The highest level of disclosure was carried out by Bank BPD West Nusa Tenggara Syariah, with a level of disclosure of $75.21 \%$. At the same time, the lowest disclosure was carried out by Bank Victoria Syariah of $51.28 \%$. This fairly good level of disclosure can be concluded because many Islamic banks are beginning to be aware of 
M. Afif Herliandi Nasution et.al. Analysis of effects of the disclosure of Islamic corporate governance (ICG) and Islamic corporate social responsibility (ICSR) on financial performance (an empirical study on the Sharia Banks in Indonesian in 2012-2020).

their responsibilities by caring for the community, the information, and God.

Table 10. Disclosure Level Based On Item

\begin{tabular}{|l|l|}
\hline Disclosure Level By Item & Average of Disclosure \\
\hline ICG Disclosure Items & $93,17 \%$ \\
\hline Sharia Supervisory Board & $0,00 \%$ \\
\hline Internal Sharia Compliance Unit & $0,00 \%$ \\
\hline Internal Shariah Audit Unit & $100,00 \%$ \\
\hline Board of Directors & $90,00 \%$ \\
\hline Committee Board & $99,08 \%$ \\
\hline Internal Control and External Audit & $100,00 \%$ \\
\hline Risk Management & $27,52 \%$ \\
\hline Investment Account Holder & Average of Disclosure \\
\hline ICSR Disclosure Items & $76,15 \%$ \\
\hline Funding and Investment & $3,06 \%$ \\
\hline Products and Services & $84,47 \%$ \\
\hline Employee & $72,39 \%$ \\
\hline Public & $39,63 \%$ \\
\hline Environment & \\
\hline \multicolumn{2}{|c|}{ Source: Data is processed by researchers in 2021} \\
\hline
\end{tabular}

From Table 10, the above can be seen that the level of disclosure of the Sharia Council is $93 \%$, but there are still sharia banks that have DPS 2 people where the recommendations of IFSB and also set in the DSN-MUI of 3 people. For Islamic banks in Indonesia who are still using the Sharia Supervisory Board, use the General Compliance Unit or Internal Audit to help them examine whether Islamic banks apply Islamic values in them.

The level of disclosure of the Sharia Council, the Committee Council, Internal Control, and the risk management of Islamic banks has a level of the disclosure above 90.00\%. It proves that Islamic banks apply good GCG to improve their quality.

In disclosing ICSR items, Islamic banks apply good responsibility even though this disclosure is only voluntary. However, it has been good because Islamic banks do not forget their responsibilities to God, society, and the environment.

\section{DISCUSSION OF RESEARCH RESULTS}

The results of this study indicate that the application of good ICG accompanied by disclosure in Islamic bank annual reports can improve financial performance. The application of ICG in Islamic banks includes the aspects of the company's good governance and fulfilling the compliance of sharia principles. ICG, which reflects all elements of Islamic banks, runs according to applicable procedures and laws and complies with Sharia principles. So that the company's wheel the company runs well and improves financial performance. One of the important elements in Islamic bank governance that are not found in conventional banks is DPS. DPS must be able to carry out its function in overseeing the compliance of Sharia aspects because whatever the financial performance of Islamic banks violates sharia principles, it is not worth anything in the Islamic perspective.

ICSR illustrates the social function of Islamic banks both from the perspective of positive law and Islam. This study indicates that Islamic banks that can carry out their social functions properly and accompanied by disclosure in annual reports can positively impact financial performance. The better Islamic banks in informing their social activities, the financial aspects will also increase.

Islamic philosophy in the form of zakat, infaq, alms, and waqf (ZISWAF) became the main program of CSR Bank Syariah. Sharia banks can act as social intermediation institutions for the ZISWAF program. Social programs will be more effective through a good infrastructure network of Islamic banks. Social and commercial functions attached to Islamic banks can become mutually beneficial. Social performance can improve financial performance and vice versa.

\section{CONCLUSION}

Based on the results of data analysis and research discussion, it can be concluded as follows:

1. ICG has a positive effect on financial performance, and this proves that good corporate governance by avoiding things that are prohibited in Islam takes an important role in improving Islamic bank's financial performance in Indonesia 
M. Afif Herliandi Nasution et.al. Analysis of effects of the disclosure of Islamic corporate governance (ICG) and Islamic corporate social responsibility (ICSR) on financial performance (an empirical study on the Sharia Banks in Indonesian in 2012-2020).

2. ICSR has a positive effect on financial performance; this result proves the company's responsibility in Islamic banks related to the environment, humans, and God also improves the performance of Islamic bank companies in Indonesia.

3. ICG and ICSR together or simultaneously have a significant effect on financial performance. It proves that the Top Management section to Lower Management Islamic banks in Indonesia can improve company performance and provide positive results for other stakeholders.

\section{RESEARCH LIMITATIONS}

In this study, several research limitations can be explained as follows:

1. Removal is only done at the Islamic General Bank (bus). Even though there are still many other Sharia Financial Institutions.

2. ICG disclosure items and ICSR used do not separate between aspects that must be disclosed (mandatory) and voluntary aspects.

\section{SUGGESTION}

Based on the limitations of the research mentioned, it can be recommended as the following:

a) For further researchers, it is recommended to expand the research object to other Islamic financial institutions (LKS), such as Islamic cooperatives, sharia pawnshops, etc.

b) It is also recommended to separate the mandatory disclosure (mandatory) and voluntary disclosure so that further research can be better directed.

Acknowledgement: None

Conflict of Interest: None

Source of Funding: None

\section{REFERENCES}

1. Abdullah, W. A., Percy, M., \& Stewart, J. (2015). Determinants of voluntary corporate governance disclosure: Evidence from Islamic banks in the Southeast Asian and the Gulf Cooperation Council regions. Journal of Contemporary Accounting \& Economics $\quad 11, \quad 262-279$. https://doi.org/10.1016/j.jcae.2015.10.001

2. Aribi, Z. A., \& Gao, S. (2010). Corporate social responsibility disclosure: A comparison between Islamic and conventional financial institutions. Journal of Financial Reporting and Accounting, Vol. 8 Iss: 2 , 7291.DOI:10.1108/19852511011088352

3. Arshad, R., Othman, S., \& Othman, R. (2012). Islamic Corporate Social Responsibility, Corporate Reputation, and Performance. International Journal of Social, Behavioral, Educational, Economic, Business and Industrial Engineering Vol:6, No:4, 643-647. https://doi.org/10.5281/zenodo.1074857

4. Bhatti, M., \& Bhatti, M. I. (2010). Toward Understanding Islamic Corporate Governance Issues in Islamic Finance. Asian Politics \& Policy-Volume 2, Number 1, 25-38.

5. Chapra, M. U., \& Ahmed, H. (2002). Corporate Governance in Islamic Financial Institutions. Islamic Development Bank.

6. Choudhury, M.A., Hoque, M.Z., 2006. Corporate governance in Islamic perspective. Corp. Gov. 6, 116-128. DOI:10.1108/14720700610655132

7. Darmadi, S. (2013). Corporate governance disclosure in the annual report: An exploratory study on Indonesian Islamic banks. Humanomics, Vol.29 No.1, 4-23. https://doi.org/10.1108/0828866131129929 5

8. El-Halaby, S., \& Hussainey, K. (2015). The Determinants of Social Accountability Disclosure: Evidence from Islamic Banks around the Worl. International Journal of Business, Vol. 20, No.3, 202-223.

9. Fahmi Irham. 2012. Analisis Laporan Keuangan. Bandung : Alfabeta

10. Farag, H., Mallin, C., \& Ow-Yong, K. (2014). Corporate Social Responsibility and Financial Performance in Islamic Banks. Journal of Economic Behavior \& Organization, 1-43. https://doi.org/10.1016/j.jebo.2014.03.001 
M. Afif Herliandi Nasution et.al. Analysis of effects of the disclosure of Islamic corporate governance (ICG) and Islamic corporate social responsibility (ICSR) on financial performance (an empirical study on the Sharia Banks in Indonesian in 2012-2020).

11. Farook, S., Hassan, M. K., \& Lanis, R. (2011). Determinants of corporate social responsibility disclosure: the case of Islamic banks. Journal of Islamic Accounting and Business Research, Vol. 2 No. 2, 114-141. https://doi.org/10.1108/1759081111117053 9

12. Hamid, A. A., Haniff, M. N., Othman, M. R., \& Salin, A. A. (2011). The Comparison Of The Characteristics Of The Anglo-Saxon Governance Model And The Islamic Governance Of IFIS. Malaysian Accounting. Review, Vol. 10 No. 2, 1-12.

13. Hasan, Z. (2011), Shariah Governance in Islamic Financial Institutions in Malaysia, GCC Countries and the UK, Ph.D. thesis, Durham University.

14. Hasan, Z. (2011). A survey on Shari" ah governance practices in Malaysia, GCC countries and the UK: Critical appraisal. International Journal of Islamic and Middle Eastern Finance and Management, Vol. 4 No. 1, 30-51.

15. Hassan, A., \& Harahap, S. S. (2010). Exploring corporate social responsibility disclosure: the case of Islamic banks. International Journal of Islamic and Middle Eastern Finance and Management, Vol. 3 Iss.3, $203 \quad-227$. https://doi.org/10.1108/1753839101107241 7

16. Ikatan Akuntan Indonesia. 2007. Standar Akuntansi Keuangan. Edisi 2007. Penerbit : Salemba Empat. Jakarta.

17. Iqbal, Z., \& Mirakhor, A. (2004). Stakeholders Model of Governance in Islamic Economic System. Islamic Economic Studies, Vol. 11, No. 2, 44-63.

18. Jumingan. 2006. "Analisis Laporan Keuangan". Jakarta : PT. Bumi Aksara

19. Kamla, R., \& Rammal, H. (2013). Social reporting by Islamic banks: does social justice matter? Accounting, Auditing \& Accountability Journal, Vol. 26 Iss6, 911 945. https://doi.org/10.1108/AAAJ-032013-1268

20. Kamaludin, (2011). Manajemen Keuangan "Konsep Dasar dan Penerapannya". Bandung: Mandar Maju.

21. KEMENKEU. (2015). Industri Perbankan Syariah Menghadapi Masyarakat Ekonomi Asean (MEA) 2015 : Peluang dan Tantangan Kontemporer. Retrieved from https://bppk.kemenkeu.go.id/
22. Khuram et al. (2012).An evaluation of corporate governance practices of Islamic banks versus Islamic bank windows of conventional banks: A case of Pakistan. Management Research Review. DOI:10.1108/01409171311315003

23. Khurshid, M. A., Al-Aali, A., Soliman, A. A., \& Amin, S. M. (2014). Developing An Islamic Corporate Social Responsibility Model (ICSR). Competitiveness Review, Vol.24 Iss 4, 258-274.

24. Lewis, M. K. (2005). Islamic Corporate Governance. Review of Islamic Economics, Vol. 9, No.1, 5-29.

25. Majid, N. A., Sulaiman, M., \& Ariffin, N. M. (2011). Developing a Corporate Governance Disclosure Index for Islamic Financial Institutions. 8 the International Conference on Islamic Economics and Finance, 1-25.

26. Mosaid, F. E., \& Boutti, R. (2012). Relationship between Corporate Social Responsibility Performance in Islamic Banking. Research Journal of Finance and Accounting, Vol.3 No.10, 93-103.

27. Munawir. 2010. Analisis Laporan Keuangan. Cetakan Kelima Belas. Yogyakarta: Liberty Yogyakarta.

28. Otoritas Jasa Keuangan. (2015). Perbankan Syariah. Retrieved from https://www.ojk.go.id/id/kanal/syariah/Page s/Perbankan-Syariah.aspx

29. Rahman, A. A., \& Bukair, A. A. (2013). The Influence of the Shariah Supervision Board on Corporate Social Responsibility Disclosure by Islamic Banks of Gulf Co-operation Council Countries. Asian Journal of Business and Accounting, Vol. 6, No.2, 65-104.

30. Sekaran, U. and Bougie, R. (2013) Research Methods for Business: A Skill-Building Approach. 6th Edition, Wiley, New York.

31. Singh, Y. K. (2006). Fundamental research methodology and statistics. (P. New Age International (P) Ltd., Ed.). New Delhi.

32. Sofyani, H., Ulum, I., Syam, D., \& Wahjuni, S. (2012). Islamic Social Reporting Index Sebagai Model Pengukuran Kinerja Sosial Perbankan Syariah (Studi Komparasi Indonesia Dan Malaysia). Jurnal Dinamika Akuntansi, 36-46.

33. Srairi, S. (2015). Corporate Governance Disclosure Practices and Performance of Islamic Banks in GCC Countries. Journal of Islamic Finance, Vol. 4 No. 2, 1-17. 
M. Afif Herliandi Nasution et.al. Analysis of effects of the disclosure of Islamic corporate governance (ICG) and Islamic corporate social responsibility (ICSR) on financial performance (an empirical study on the Sharia Banks in Indonesian in 2012-2020).

34. Statiskian. (2019). Penjelasan Teknik Sampling Dalam Penelitian. Statiskian. https://www.statistikian.com/2017/06/teknik samplingdalampenelitian.htm

1/amp\#targetText=Sampling jenuh adalah Teknik penentuan,kecil\%2C kurang dari 30 orang

35. Williams \& Zinkin. (2010). Islam and CSR: A Study of the Compatibility Between the Tenets of Islam and the UN Global Compact. Journal of Business Ethics 91(4):519-533. DOI:10.1007/s10551-0090097-x

36. Yadiat, Winwin., Gustani., \& Amrania, Gia. (2017). The effect of Islamic Corporate Governance (ICG) and Islamic Corporate Social Responsibility (ICSR) Disclosures on Market Discipline with Financial Performance Used as Intervening Variables (Empirical Study on Shariah- based Banks Operating in QISMUT Countries). International Journal of Applied Business and Economic Research.

37. Yusuf \& Bahari. (2015). Islamic corporate social responsibility in Islamic banking: Towards poverty alleviation. Ethics, Governance and Regulation in Islamic Finance

How to cite this article: M. Afif Herliandi Nasution, Azhar Maksum, Idhar Yahya. Analysis of effects of the disclosure of Islamic corporate governance (ICG) and Islamic corporate social responsibility (ICSR) on financial performance (an empirical study on the Sharia Banks in Indonesian in 2012-2020). International Journal of Research and Review. 2022; 9(2): 368-380. DOI: https://doi.org/ 10.52403/ijrr.20220248 